\title{
ENTREPRENEURIAL UNIVERSITY: TOOLS AND MODELS FOR INTEGRATING THE THIRD MISSION IN EDUCATION INSTITUTIONS
}

\author{
LA UNIVERISIDAD EMPRENDEDORA: HERRAMINETAS Y \\ MODELOS PARA LA INTEGRACIÓN DE LA TERCERA MISIÓN EN \\ LAS INSTITUCIONES EDUCATIVAS
}

\author{
Svetlana Viktorovna Shvedova \\ Irina Mikhailovna Maevskaya
}

\begin{abstract}
University spinoffs have remarkably strengthened the linkage between universities and industry. The number of technology patents and spinoffs coming out of university research has a significant impact on regional economic and social development. To further highlight the importance of university spinoffs, the article aims to review available literature on university spinoffs and present a comprehensive overview of what university spinoffs are, why they are important, what makes them significant, and how they are or can be created. In addition to reviewing existing models of University spinoff creation, the authors propose a new, multi-stage, holistic model.

The authors explore how universities can promote new research-based businesses by suggesting that the nature of the supplied support depends on demands of spin-off companies. Adopting a demand-side perspective, the authors seek to understand the challenges faced by new technology businesses and hence identify how universities can assist their start-up and development.

The paper nuances the common conception of a university as one uniform entity in relation to spin-offs, and assesses the literature including all levels within the university. The analysis of EU spin-off models, activities, methodologies and policies is based on the outcomes of the ERASMUS+ project "University-Enterprise Cooperation via Spin-Off Companies Network (UNISON)".
\end{abstract}

Key words: Commercialization of knowledge, entrepreneurship education, entrepreneurial university, spinoff company, start-up support

\section{RESUMEN}

Subempresas universitarias han reforzado el vínculo entre las universidades y la industria. Unos patentes de tecnologías y unas empresas aparecidas gracias a las investigaciones llevadas a cabo por las universidades tienen un impacto relevante a las economías regionales y el desarrollo social. Para hacer hincapié en la importancia de las subempresas universitarias el articulo tiene por objetivo revisar las referencias accesibles sobre las subempresas universitarias y presentar un panorama exhaustivo de lo que son, porque son importantes, que las hace significantes y como se aparecen. Después de revisar los modelos existentes de subempresas universitarias, los autores proponen un modelo nuevo de etapas mÚltiples y holístico. 
Los autores exploran como las universidades pueden promover nuevos negocios basados en las investigaciones por sugerir que la esencia de del apoyo suministrado depende de la demanda de las subempresas. Adoptando la perspectiva de demanda, los autores buscan mejorar la comprensión de los desafíos que se encuentran los negocios de nuevas tecnologías y por lo tanto identificar como las universidades pueden apoyar a sus puestas en marcha y desarrollo.

El artÍculo matiza la concepción general de la universidad como una entidad homogénea en la relación con subempresas y evalúa la literatura incluyendo todos los niveles dentro de universidad. El análisis de los modelos de subempresas en la UE, actividades, metodologías y políticas están basadas en los resultados del proyecto Erasmus+ "La cooperación Universidad-Empresa vía las redes de subempresas (UNISON)".

Palabras clave: comercialización del conocimiento, la educación empresarial, la universidad emprendedora, subempresas, apoyo a puesta en marcha. 


\section{INTRODUCTION}

Over past two decades, the field of academic entrepreneurship has found greater visibility, and universities are being increasingly considered as a source for creation of high-technology firms. With greater attention focused on the linkage between science, technology, and university spinoffs, universities are moving from their traditional roles of research, teaching, and knowledge dissemination to a more advanced role of creating spinoffs and promoting academic entrepreneurship (Lerner, 2004).

Cohen and colleagues (1998) highlighted the need to emphasize the transfer and commercialization of knowledge generated within universities. Other scholars also point towards the growing need for universities to disseminate their generated knowledge beyond the narrow confines of the academic community (Branscomb et al., 1999; Hague \& Oakley, 2000). Universities and governments, both in technologically advanced and developing nations, have shown greater interest in academic entrepreneurship and university spinoffs as a means of building links between universities and industry.

The Bologna process definitely made a positive effect on the way entrepreneurial knowledge is spread. The 46 Bologna signatory countries met in London in May 2007, recommended such measures as the recognition of non-formal learning, the development of flexible curricula to accommodate student and staff mobility, and enhanced university-employer collaboration in innovation and knowledge transfer.

If it is to make a success of the Lisbon strategy for growth and employment, Europe needs to stimulate the entrepreneurial mindsets of young people, encourage innovative business start-ups, and foster a culture that is friendlier to entrepreneurship and to the growth of small and mediumsized enterprises (SMEs). The important role of education in promoting more entrepreneurial attitudes and behaviour is now widely recognized.

In a 2014 Bologna Process Researchers' Conference Report, the concept of 'the third mission of education' was raised. It seems that in addition to teaching and learning, a third mission for the university should be innovation, allowing universities to network ideas, concepts and best practice all in pursuit of the core goal of sustaining a knowledge economy with social values. In essence, the university as academic innovator, incubator and inclusive institution. Universities should see themselves as entrepreneurial organizations and environments held together by common values/missions and not detailed control systems. To develop as an entrepreneurial organization with an entrepreneurial culture the entrepreneurial activities should be established in the strategy.

\section{ENTREPRENEURSHIP EDUCATION}

More and more universities have implemented measures to improve their entrepreneurial climate with the aim of fostering the entrepreneurial propensity of students and researchers (Rasmussen \& Borch, 2010). Universities can encourage academics and students to look beyond classrooms and laboratories, offering courses in entrepreneurship (Boh et al., 2016). There is growing evidence that the social and organizational context at universities has a substantial impact on the entrepreneurial attitudes and activities of academics and students (Walter et al., 2013).

Worldwide, the number of universities providing entrepreneurship support for their students, graduates, researchers and professors is growing. That encompasses both entrepreneurship education, with its two main objectives of generating motivation and attitudes for entrepreneurship and the skills and competencies needed to successfully start-up and grow a business, and the 
provision of start-up support. Different strategies have been advanced and various forms of support established including actors both within and outside universities. Tailored practices have emerged in educating future entrepreneurs and in helping them to take their first steps in forming and growing a business. Universities have established dedicated start-up support services, often also as single units that centralise and steer a multitude of activities, to offer would-be entrepreneurs and those already in the start-up process consultation and access to networks and premises. Rewarding those who are designing and implementing innovative and high quality pedagogical material and teaching, and those who are sharing and promoting the dissemination of ideas and good practices is of crucial importance for promoting continuation of activities and encouraging professors, researchers and university administration to join.

At higher education level, the primary purpose of entrepreneurship education should be to develop entrepreneurial capacities and mindsets. In this context, entrepreneurship education programmes can have different objectives, such as: a) developing entrepreneurial drive among students (raising awareness and motivation); b) training students in the skills they need to set up a business and manage its growth; c) developing the entrepreneurial ability to identify and exploit opportunities. Graduates' start-up is one of a range of possible outcomes.

Entrepreneurship education in universities has come a long way since the first entrepreneurship course was held by Professor Myles Mace at Harvard. The purpose of university entrepreneurship education is two-fold. Contributing to the creation and development of entrepreneurial attitudes and motivations to start-up a firm is as important as developing the skills needed to successfully run and grow a business venture. Increasing demand for higher education, the above mentioned globalization of „tasks "e, changing knowledge structures and transmission channels, evolving dynamics between industry, government and the education sector, as well as societal demands gave rise to entrepreneurship education in universities. An international study ${ }^{1}$, comparing tertiary education students ${ }^{\text {ee }}$ attitudes to entrepreneurship in 19 different countries across the globe, showed that $43 \%$ of students intend to pursue some form of independent employment five years after graduating (Guesss,2009).

It is important that entrepreneurship education is taken serious by both students and teachers (which does not mean it cannot be fun), but it should also help to fulfil the academic requirements for both sides. It is important to build and expand linkages between research and teaching, for example by getting doctoral students to work on an entrepreneurship education related research topic. Inviting international visiting entrepreneurship professors on a regular basis strengthen the research base, the teaching students, and training ,trainers ${ }^{\text {ee }}$ efforts.

Ideally, all students have access to a wide range of entrepreneurial learning opportunities inside and outside their courses of study. Increasing take-up rates will require both expanding and tailoring the offer in entrepreneurship education. The goal is to develop entrepreneurial graduates who are selfconfident, capable, experienced and motivated to think and act entrepreneurially. With suites of courses, the offer in entrepreneurship education can be expanded and tailored to different student interests and needs.

Entrepreneurship education should be organized in a dynamic way, taking into account research and real-business needs. To ensure this, regular performance assessment exercises are useful, including regular feedback sessions with people from the business community, alumni entrepreneurs and students and to track and survey alumni with entrepreneurial careers.

The entrepreneurial university is involved in partnerships, networks and business activities with public and private firms and governments to find collaboration and interactions with the aim of linking education, research and activities with technological, social and economic development 
(Guerrero \& Urbano, 2012b). Guerrero \& Urbano (2012b) propose a model of entrepreneurial university with the following features:

1. Formal factors: Entrepreneurial organizational and governance structure, support measures for entrepreneurship, entrepreneurship education.

2. Informal factors: University community's attitudes towards entrepreneurship, entrepreneurial teaching methodologies, role models and reward system.

3. Resources: Human capital, financial, physical and commercial.

4. Capabilities: Status and prestige, networks and alliances, localization.

\section{SPIN-OFF THEORIES}

Assisting the establishment of new firms is a key objective of university entrepreneurship support, but not its only one. Creating entrepreneurial mindsets that drive innovation in existing firms is of equal importance, yet success is much more difficult to measure. The economic recession has triggered cuts in government funding and resource allocation for universities and put entrepreneurship education under increased performance pressure. Demonstrating the achievements of entrepreneurship education towards external funders remains a key challenge, as evaluation efforts are still considered to be relatively weak or underdeveloped (Wilson, 2008). The co-existence of tangible outputs, such as, for example, the number of spin-offs and start-ups assisted, and intangible outcomes - creating entrepreneurial mindsets - remains a key challenge. The qualities of the entrepreneurs are essential in explaining spin-off creation and success (Clarysse et al. 2011a). Moreover, the university context plays an important role,both in relation to the individuals starting university spin-offs and their ventures. Some university characteristics associated with spin-off firm formation are well established in the literature, such as intellectual eminence (Di Gregorio and Shane 2003), faculty quality(Powers and McDougall 2005), or scientific productivity (Van Looy et al. 2011). It is increasingly recognized that entrepreneurs and their ventures are imprinted by their founding environment (Beckman and Burton 2008; Bercovitz and Feldman 2008). Hence, it is clear that both the extent of venture creation and the type of ventures created are influenced by university-level factors.

Understanding how universities can promote the establishment and growth of spin-offs requires detailed knowledge about how these firms develop and the type of conditions and support that facilitate their success. Absent this knowledge risks a mismatch between the supply of support provided and the demand for support from the spin-off firm. We adopt an entrepreneurial competency perspective that is developed to understand how university spin-offs emerge (Rasmussen et al. 2011).

Support systems for academic entrepreneurship and spin-offs in general include both university internal and external actors. The aim should be to develop a shared and well-communicated vision and to implement a joint strategy to promote academic entrepreneurship. A concerted approach is needed to take stock of the range of activities, the people behind it and the resources devoted, to identify areas of overlap as well as potentials for synergies and untapped resources. Decisions about resource allocation should be driven by strategic choices that the university makes regarding the areas of technology and the various modes of transfer - licensing, sponsored research, start-ups, and other mechanisms of technology transfer that are focused more directly on stimulating economic and regional development, such as incubators and science parks. Licensing and sponsored research can generate a stream of revenue, whereas investment in spin-offs and startups could yield returns in the long run. 
University spinoffs have remarkably strengthened the linkage between universities and industry. The number of technology patents and spinoffs coming out of university research has a significant impact on regional economic and social development. To further highlight the importance of university spinoffs, the aim of this article is to review available literature on university spinoffs and present a comprehensive overview of what university spinoffs are, why they are important, what makes them significant, and how they are or can be created. In addition to reviewing existing models of university spinoff creation, we also propose a new, multi-stage, holistic model.

What is a University Spinoff? According to Pirnay and colleagues (2003), "spinoff" is a fuzzy and general concept that covers a wide variety of phenomenon among which a university spinoff represents only one specific type. This assertion may also lead to a confused understanding of spinoffs, which may impede definitional understanding of the concept. There have been several attempts in the academic literature to define university spinoffs, and although they are not all consistent, common threads may be identified. They represent different perspectives that many not be compatible. Table 1 presents four definitions of university spinoffs, from which we can distil the following salient characteristics of a university spinoff:

1. the parent organization from which the innovation emerges has to be a university or academic institution;

2. the output that is a university spinoff has to be a separate legal entity and not an extension or controlled body of the university;

3. the new entity has to exploit knowledge produced from academic activities or academic pursuits;

4. the spinoff should be aimed at profit generation and commercialization of technology.

University spinoffs contribute to the economic development of the locality to which they belong. Firstly, they create business opportunities by translating research results into workable technologies leading to market solutions. Secondly, they typically conduct most of their basic activities locally (e.g., hiring, sourcing supplies, production) and thus have significant multiplier effects on local economic activity. Spinoffs frequently serve as catalysts for the formation of geographic clusters of new firms in particular technologies (Lowe, 2002).

University spinoffs make use of university technologies that might otherwise would go undeveloped. Researchers have identified two ways that spinoffs enhance the development of technology:

1. Spinoffs provide a mechanism for firms to commercialize inventions that have very high uncertainty, which reduces interest from other larger establishments (Etzkowitz, 2003)

2. Spinoffs provide a way to ensure inventor involvement in the subsequent development of university technologies, which is crucial when technologies are based on tacit knowledge (Shane, 2004).

University spinoffs also provide effective mechanisms for involving the inventor of the technology in the process of commercialization, which is a necessary condition for the development of products or services from university technology (Hindle\&Yencken, 2004; Jensen \&Thursby, 1998). University spinoffs achieve inventor involvement because many scientists perceive that spinoffs are better places to work than established firms, where the projects may be less interesting or challenging (Kenney, 1986). As a result, inventors are more inclined to work with new companies seeking to commercialize their university inventions than they are to work with established companies seeking to commercialize their own inventions. 
Startups firms focus more on technology development as opposed to other aspects of business, and university researchers tend to be more interested in technology development than in other aspects of business. Also, equity is a more effective tool to ensure inventor involvement in spinoffs than other forms of compensation (Geuna\&Nesta, 2006). Spinoffs can provide inventors with equity holdings more easily than established firms because the distribution of equity at the time of firm founding does not involve the transfer of equity from someone who has it to another individual, as is the case when equity is distributed after founding.

Attracting and retaining productive science and engineering faculty can be a substantial challenge otherwise, and the potential for university spinoffs can help on both counts. By allowing faculty to supplement their salaries with equity in their own companies, universities provide a financial mechanism to retain and recruit faculty, particularly in the biomedical areas, where this approach is similar to the use of practice plans common with clinical faculty in medical schools (Jones \& Gold, 2001). In the discipline of biological sciences, researchers have observed that allowing faculty to found spinoffs reduces the number of faculty leaving the university to take higher paying industry jobs (Powell \& Owen-Smith, 1998).

\section{UNISON PROJECT: SPIN-OFF MODELS AND BEST PRACTICES}

In 2016 UNISON project started in the framework of ERASMUS+ programme targeted to promoting Bologna process implementation through enhancing university-enterprise cooperating via spin-off companies best practices. UNISON delved into the mechanisms involved in the transfer and commercialization of technology and technology, thus helping to overcome the traditional difficulties that the institutions of higher education have in trying to develop projects in collaboration or in a business key. In this sense, the experience of non-development of technologybased companies (university spin-offs) offers the possibility of lifting or working together with a new phase based on the exchange of experiences not of entrepreneurship. Also, the project activities seek to promote the transmission and application of business experiences in education, training and youth work. During three years, the project consortium members made in-depth study of spin-off companies' models, analysis of best practices of different countries and universities. Here we present the research findings of the UNISON project.

The creation of the technology used by a university spinoff is a multi-stage process. Funding from the governments, industry, and foundations are used to support scholarly research in science and engineering. In a typical process, some of this research results in the creation of new technology that is then brought to the attention of the university. The university technology-licensing office may then decide whether or not to seek intellectual property protection for the invention, after which efforts may be made towards licensing the technology. Policies regarding the retention and protection of intellectual property will vary from university to university, but in most cases, established companies are the licensees of university inventions, and in some cases, newly formed companies are the licensees. Beginning with the initial research phase, the process of university technology development involves significant amounts of hard work, with only some efforts leading to outcomes that mark progression to the next stage.

The project team and Instituto Politecnico de Coimbra in particular analyzed the existing spin-off models which are the following: 


\section{LINEARMODELS}

1.1 Ndonzuan, et al. (2002) Model

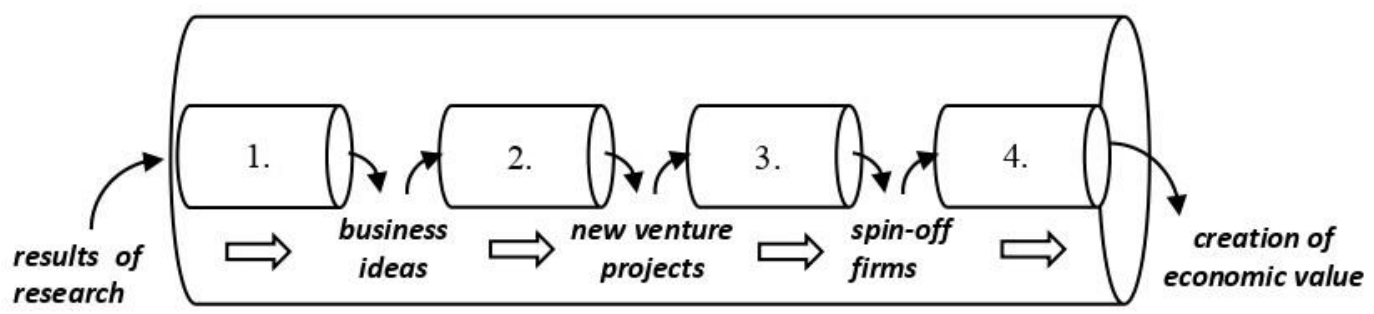

Figure 1. The global process of valorisation by spin-offs

Source: Ndonzuau, F.N., Pirnay, F. and Surlemont, B. (2002).

According to the Ndonzuan, et al. (2002) model, the academic spin-offs creation involves four successive stages, which are not wholly independent of each other, as follows:

Stage 1: to generate business ideas from research; Stage 2: to finalize new venture projects out of ideas; Stage 3: to launch spin-off firms from projects; Stage 4: to strengthen the creation of economic value by spin-off firms.

\subsection{Vohora et al. (2004) Model}

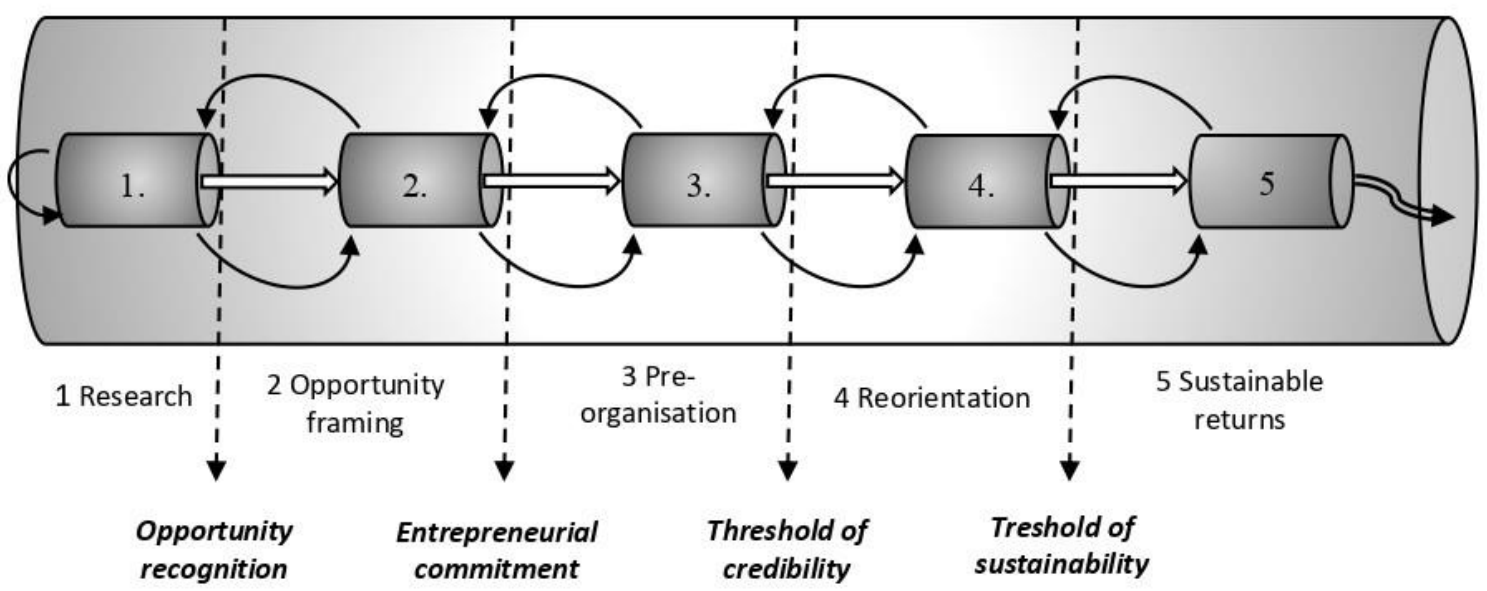

Figure 2. The development of spin-off companies according to Vohora et al. (2004)

Source: Sven H. De Cleyn and Johan Braet (2010).

This model has the same basic characteristics of linearity and selection mechanisms aftereachdevelopmentphaseasintheNdonzuauetal.(2002)model.Themoststriking difference is the explicit representation of feedback mechanisms between each of the development phases, pointing the need for a reflexive loop to improve future developments along the chain.

\subsection{Spin-off Stages Model}

The Spin-off stages model describes the evolution of new ventures, emphasizing the sequential nature of venture development. This model follows the flow of funding, resources and intellectual property through the following stages: 


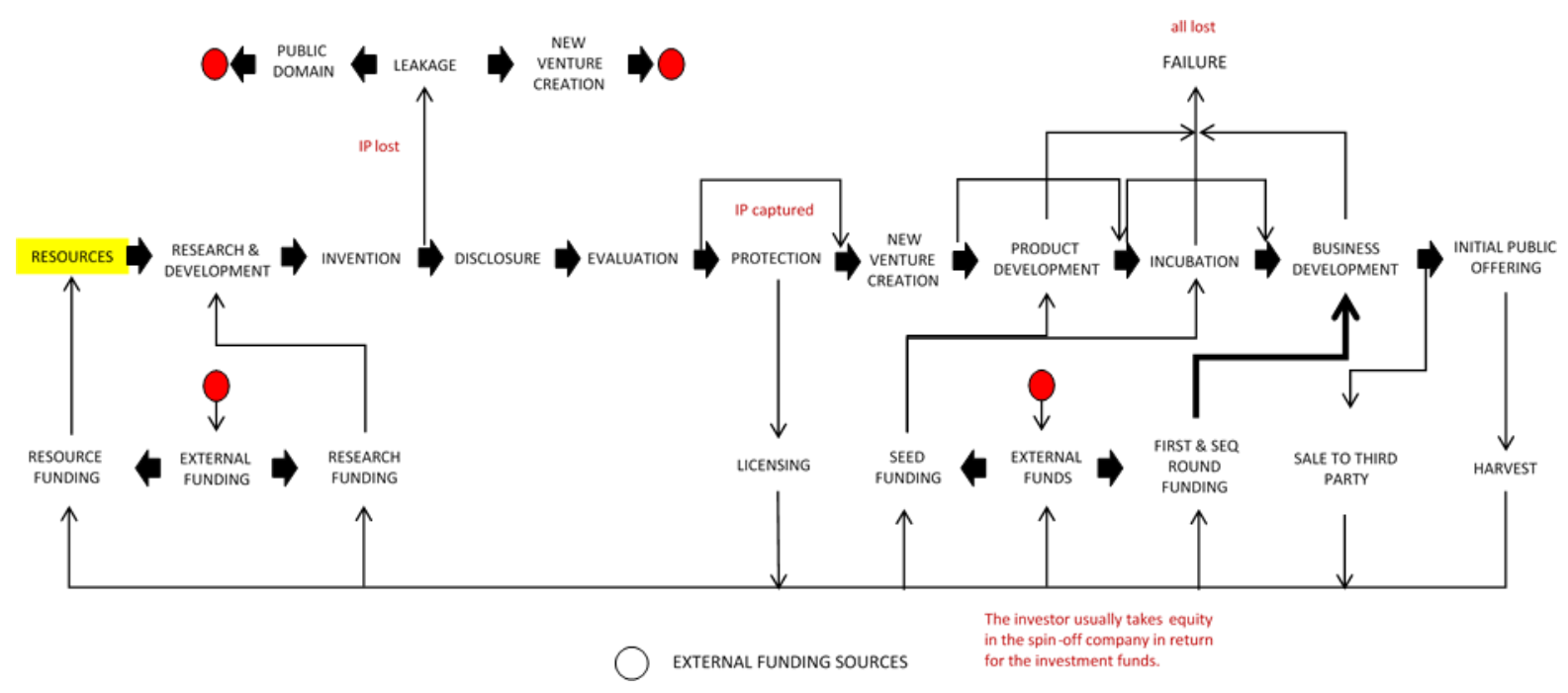

Figure 3. Spin-off stages model

Source: Roberts Edward B. and Malone Denis E.(1996).

According to the authors, the main properties that contribute to progress through the model stages are entrepreneurial drive, technical capabilities, market orientation and a have product idea. Entrepreneurial drive and technical capabilities are regarded as essential. The additional paths created by the existence of products or market perspectives strongly contribute to the success of a new venture. These properties are important even at the founding stage.

\section{PULL/PUSHMODELS}

2.1 Technology push with independent principal groups

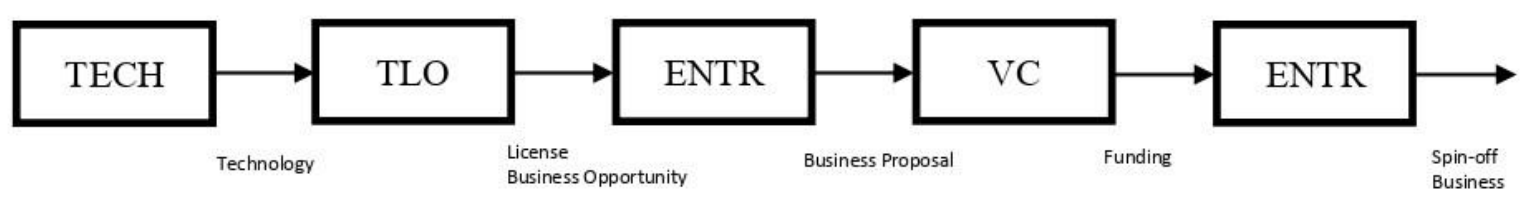

Figure 4. Technology push with independent principal groups

Source: Roberts Edward B. and Malone Denis E.(1996).

In this model, the role of each of the four principal groups is clearly separate and the process follows the sequence of the stages in a logical manner. The technology originator (TECH) has the role of providing technology to the technology licensing office (TLO), which, in turn, seeks and finds an entrepreneur (ENTR), from within or more usually from outside of the organization. For this reason, the process is regarded as one of technology push. Business pull is exerted in this model when the R\&D tasks of the technology originator are influencedbytheexternalenvironmenttocarryoutresearchinareaswherethere are potential business opportunities. 
2.2 Technology push/business pull with an entrepreneurial technology originator

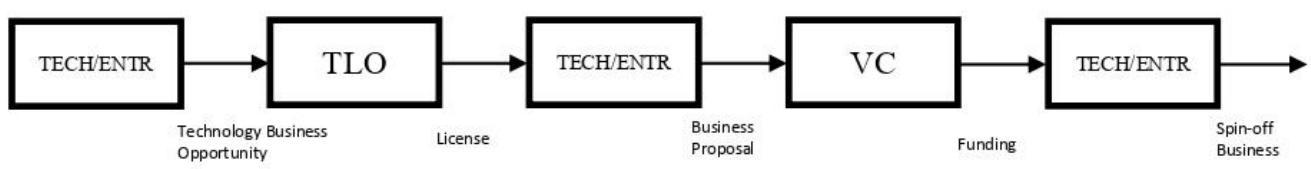

Figure 5. Technology push/business pull with an entrepreneurial technology originator.

Source: Roberts Edward B. and Malone Denis E.(1996).

In this model, the technology originator (TECH) is the same person or group as the entrepreneur (ENTR), which increases the effectiveness of technology transfer. Furthermore, the technology is more likely to be attuned to use by a spin-off, since it was the objective of the technology originator when the research and development work was being carried out.

2.3 Technology push/business pull with an entrepreneurial technology originator and an internal venture capital fund

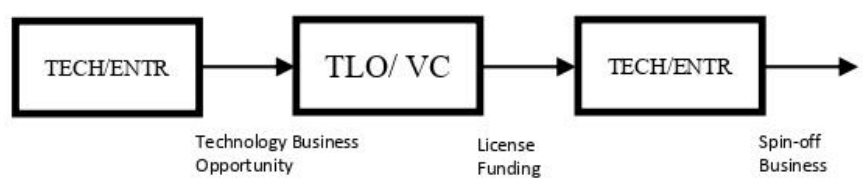

Figure 6. Technology push/business pull with an entrepreneurial technology originator and an internal venture capital fund

Source: Roberts Edward B. and Malone Denis E.(1996).

According to this model, the functions of the technology licensing office (TLO) and the venture capital fund (VC) are combined, i.e., the TLO has a venture capital fund at its disposal. This model is the suitable starting point in an environment in which spin-off ventures are not common and the R\&D organization has the objective of generate spin-offs to: i) transfer technology; ii) provide investment opportunities and returns; and iii) over time create an environment where spin-offs are more common.

2.4 Business pull with internal venture capital funds

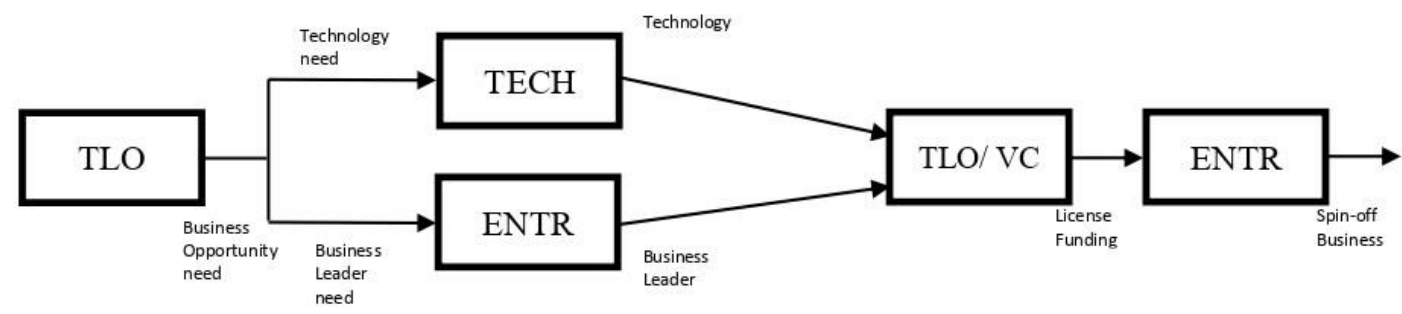

Figure 7. Business pull with internal venture capital funds

Source: Roberts Edward B. and Malone Denis E.(1996). 
This model advocates that, in a context that is poor in venture capital and where spin-offs are uncommon, the R\&D organization chooses to develop a venture capital fund to increase spin-off activity. Sometimes an outside venture capitalist fulfils the role of the organization's venture capital fund. The R\&D organization has a strong need to use technology to generate new spin-off ventures. The successful use of this model depends on: 1 generating sufficient returns to the fund, thus ensuring that it is worth while for the R\&D organization to continue with the fund, making visible progress towards the achievement to the objective of changing the external environment. Business pull with an entrepreneur/venture capital fund alliance

This model predicts that, in the well-developed spin-off environments, alliances are formed between experienced entrepreneurs and venture capital funds to discover and use technology-based business opportunities that in $\mathrm{R} \& \mathrm{D}$ organizations.Ingeneral,thetechnologylicensingofficeoftheR\&Dorganization takes an active role in finding suitable technologies to satisfy the entrepreneur's need. The entrepreneur will not have any involvement in the invention process.

\section{HOLISTIC MODEL}

A holistic model to overcome the gaps found in the linear models. 


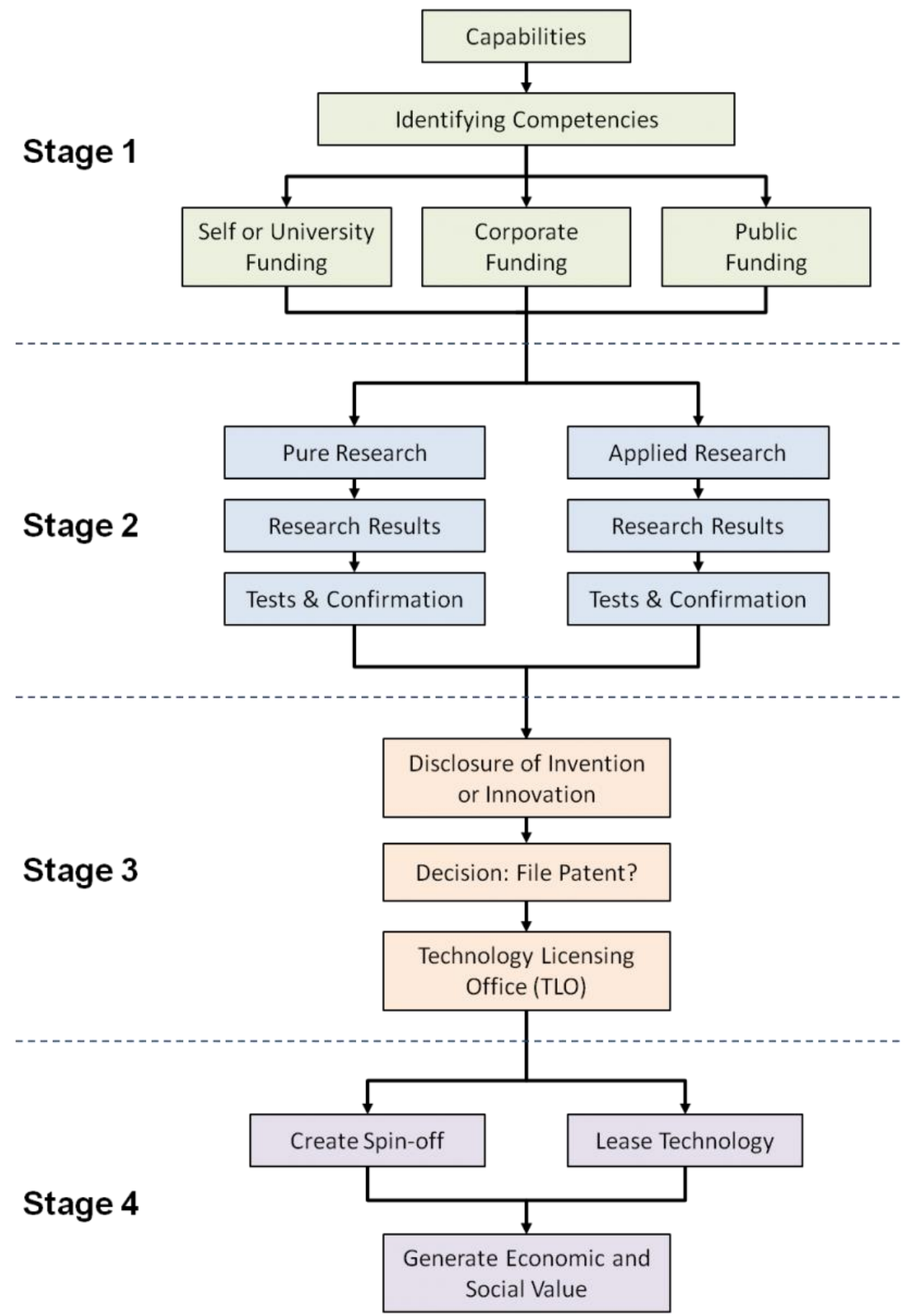

Figure 8. Holistic model

Source: Pinaki Nandan Pattnaik and Satyendra C. Pandey (2014).

The holistic model comprises the following 4 stages, as illustrated in figure 9:

Stage 1 - Build the appropriate capabilities and competencies, which are fundamental determinants of creating market viable technology spinoffs.

Stage 2 - Check the reliability, validity and viability of the value proposal, no matter if it comes from fundamental or applied research.

Stage3-ThenatureoffundingtermsandconditionsdetermineiftheHEIorthe innovator may or may not to file a patent over that knowledge. 
Stage 4-The role of a technology licensing office is to identify the potential to create commercially viable business opportunities, looking after financial returns to the inventor and university, job creation, and economic development.

\section{EVOLUTION MODEL OF YENCKEN ANDGILLIN}

According to the evolution model of Yencken and Gillin, the interactions among entrepreneurship and external knowledge inputs determine the linearity of the spin-offs creation process, in an iterative and messy dynamics, as illustrated in figure 10. The upper circles depict the importance of entrepreneurial inputs and the access to it, while the lower triangles emphasize the required external knowledge inputs.

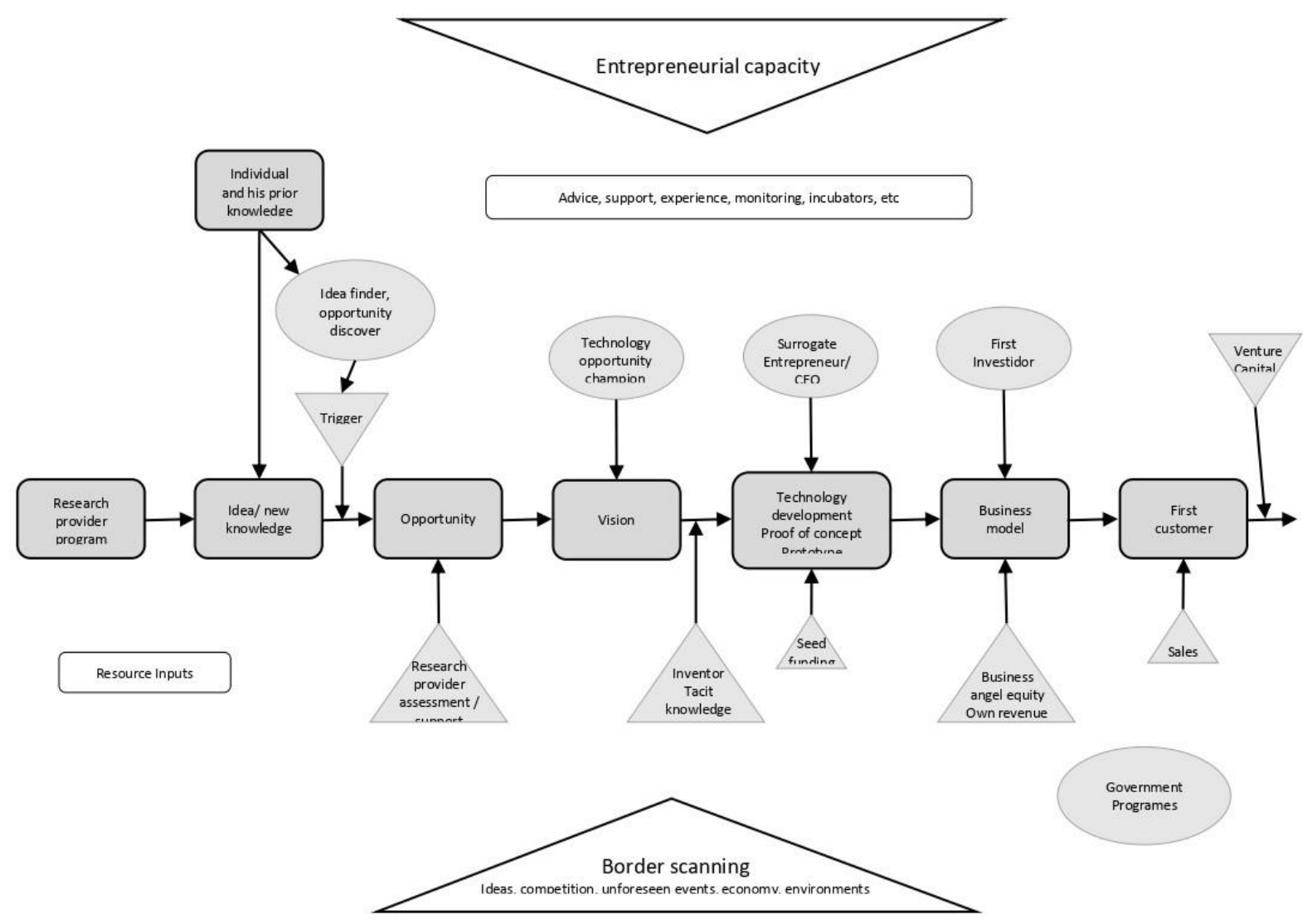

Figure 9. The development of spin-offs according to the evolution model of Yencken and Gillin Source: Sven H. De Cleyn and Johan Braet (2010). 


\section{INTEGRATED EVOLUTIONMODEL}

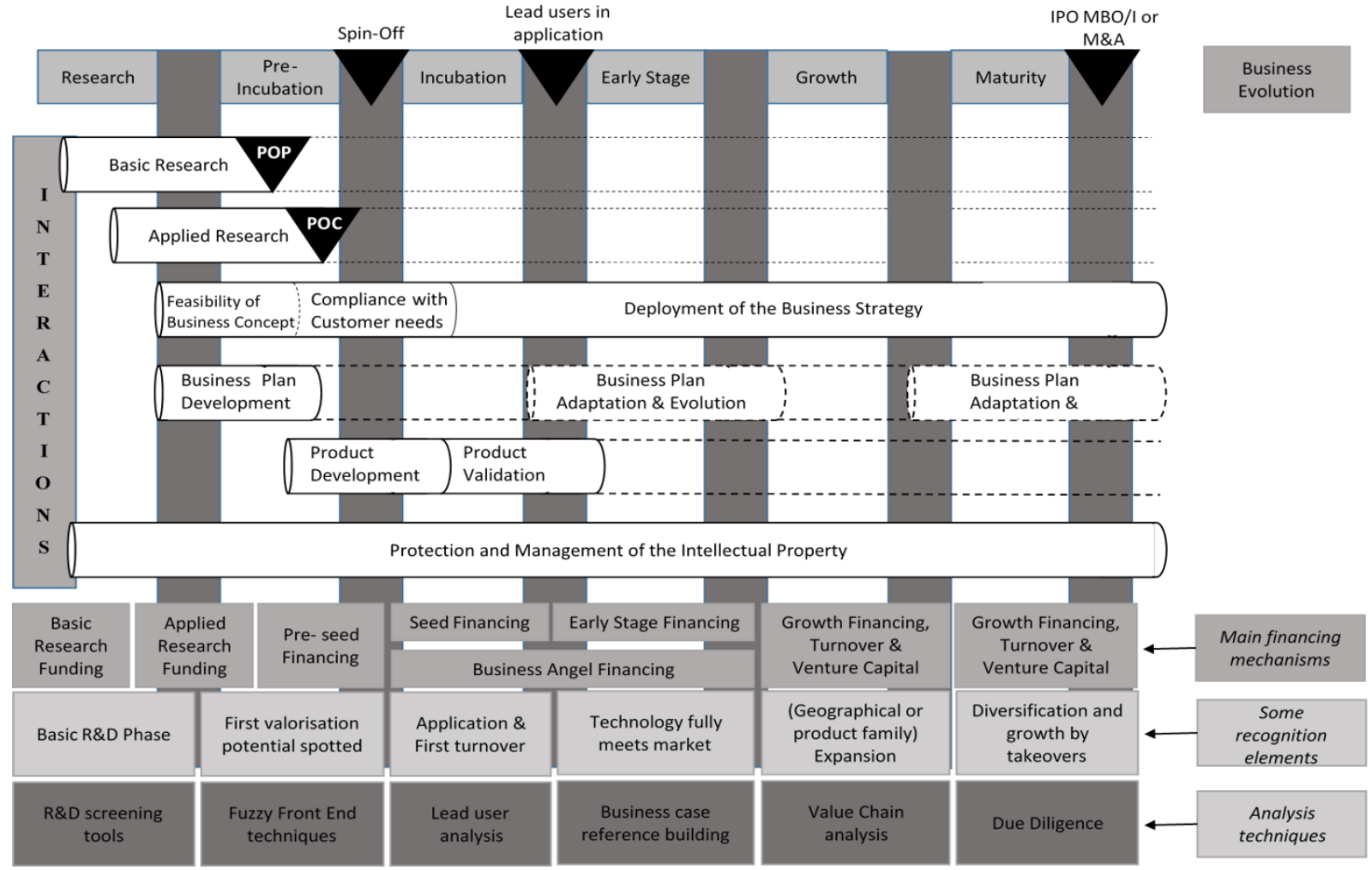

Figure 10. Integrated evolution model of Braet and De Cleyn

Source: Sven H. De Cleyn and Johan Braet (2010).

The integrated evolution model provides an entire framework that links both the business and financial evolution of a spin-off and to the content of the evolution of a venture, according to the following characteristics: i) the starting and end point of the different stages are dynamic; ii) the stages are represented as independent of each other, but each stage has interrelations with and feedback loops to the other stages; iii) the Initial Public Offering (IPO) or Merger and Acquisition (M\&A) may not be seen as the end point of the evolution of an innovativeidea; iv) the model discusses the situation for a single-product spin-off venture.

\section{Understanding how and why universities support their USOs}

USOs are sometimes defined as all new firms exploiting university-generated intellectual property (Di Gregorio and Shane 2003), or more broadly as firms taking advantage of all types of university knowledge, including for example student start-ups (Mars et al. 2008). In this paper we take a more restrictive definition USOs as new ventures initiated within a university setting, based on technology derived from university research (Rasmussen and Borch 2010). We make this choice because for these kinds of ventures, the university context is important and the extent and type of venture creation is clearly influenced by university-level factors. Some university characteristics associated with USO formation are well established in the literature: spin-off activity relates to universities' intellectual eminence (Di Gregorio and Shane 2003), faculty quality (Powers and 
McDougall 2005), or scientific productivity (Van Looy et al. 2011). What is less clear is how such university-level factors lead to USOs' establishment and subsequent performance.

Much research on universities' entrepreneurial capability focuses on 'what' universities can do to support USOs (Bruneel et al. 2010; Rothaermel et al. 2007) at the expense of 'why' universities' might choose to use their scarce resources on supporting USOs at a time when they are under many intense competing demands from outside (Ćulum et al. 2013; Damme 2009; Enders and Boer 2009; Jongbloed et al. 2008). University management literature (Clark 1998a; Powell and Dayson 2013) has been at best rather normative, describing supporting entrepreneurship and venturing as something that university leaders can insert into their institutions' organisational DNA. What is missing here is an understanding of how those support activities, which are often at the institutional periphery, fit within university's institutional architectures (Vorley and Nelles 2012). Better understanding what universities can do therefore needs to be better rooted in an understanding of why universities might support USOs given the competing pressures they face. We do this by firstly looking at how the university can realistically support new ventures as seen from the USO's perspective. Next, we look at university decision-making approaches, conceptualised through a stakeholder approach, and then identify four areas by which these various support activities might become more salient to universities, who then in turn may make them more central to their core institutional missions.

Universities are traditionally not set up to serve the needs of new ventures. The venture creation process is highly complex involving a range of different actors. Recent conceptualization show that universities may support their USOs in gaining three kinds of critical entrepreneurial competencies (Rasmussen et al. 2014; Rasmussen and Wright 2015):

1) developing a viable business opportunity (opportunity development)

2) involving and supporting individuals that provide meaning and energy to the entrepreneurial process (championing)

3) accessing resources necessary to develop the new venture (resource leveraging)

With entrepreneurial competencies consisting of these three elements, university capability can be defined in terms of what universities do to imbue USOs with those competencies.

Firstly, USO founders' and managers' networks and experiences are usually more technologically oriented than market oriented: when exploring possible technology applications, USOs may limit their search to familiar knowledge areas or a few alternative uses (Zahra et al. 2007). Conversely, considering alternative applications more broadly and synoptically increases the chances of developing a high performing business. This ability to improve and alter the opportunity according to new insights can be regarded as an opportunity development competency (Rasmussen et al. 2011). This competency is dependent on high technology expertise combined with industry or market knowledge.

Universities may support USO's opportunity development actively or passively (Bozeman 1993; Coursey and Bozeman 1993). Active support may come through 'TTOs' activities aiming to actively place resources at USOs disposal (Auten et al. 1984; Bozeman and Landsbergen 1989; Di Gregorio and Shane 2003; O'Shea et al. 2005). Passive support involves making resources (more) freely available for firms to access including research, knowledge, demand for services, complementary firms and human capital (Benneworth 2007; Bozeman et al. 1986; Clark 1998b; Moray and Clarysse 2005; Rothaermel et al. 2007).

Secondly, the role of the local work environment is particularly important for USOs because these firms are usually developed by teams where several persons play an active championing role (Vanaelst et al. 2006). Potential entrepreneurs are discouraged where current local work 
environments are not actively entrepreneurial (Bercovitz and Feldman 2008). Hence, support from scientific colleagues, university managers, T'TO staff, and people in the external network of the university is often critical, particular in early stages (Rasmussen et al. 2011). Few USOs start without significant involvement from the inventors or scientists behind the technology, the university environment can facilitate or hinder such involvement. Moreover, it is crucial for emerging USOs that new individuals with industry and business experience become involved as champions developing the venture. In early stages, the university environment may be an important catalyst for attracting champions with relevant expertise to join or support the venture. Universities may support championing both individually and institutionally (Rasmussen et al. 2011). Academics may champion ventures in which they have a shareholding, or seek to create future employers for their graduates, partners for research projects or customers for consultancy (D'Este and Perkmann 2011; Vestergaard 2007; Zomer et al. 2010).

Universities as institutions may enthusiastically encourage venturing and their own stakeholders to support USOs (Braun 2011).

Thirdly, creating a new business activity based on research is typically extremely resource demanding because of parallel needs for technological, market and organizational development along lengthy development paths. A key resource for early stage USOs is the university scientists behind the commercialised technology. Unsurprisingly many studies have confirmed that academics with access to more resources are more likely to form USOs (Landry et al. 2006). Several studies have emphasised the role of academics' social capital and networks (Murray 2004). Where new venture founders have relationships with venture investors they are most likely to receive venture funding and are less likely to fail (Shane and Stuart 2002). In addition to academic scientists' roles, the resource acquisition process is highly iterative involving many different actors with appropriate competencies (Rasmussen and Clausen 2012). Universities contribute to resource acquisition and leveraging, providing access to physical infrastructure and tangible resources such as laboratories, specific equipment, specific material (cell lines etc.) and even venture financing (Etzkowitz and Klofsten 2005). Universities may also provide intangible resources: directly recommending USOs to investors, formally acknowledging their USOs, or offering locations on a university-owned high-technology site, all of which may function as quality marks for potential stakeholder (Smith and Bagchi-Sen 2012).

Universities' wider networks may help USOs to access resources, for example directly organising events to sell into the university's strategic partners, or a cluster of industrial partner firms - with technology needs capable of providing sophisticated demands to USOs - on site (Benneworth and Hospers 2007a; Benneworth and Hospers 2007b).

Although universities can offer these capabilities to firms, there is no automatic reason why they would choose to support USOs. For all those areas, it is possible to think of reasons why universities might choose to support their USOs; opportunity development could potentially lead to discussions with businesses leading to applied or joint research projects. But it is likewise possible to think of reasons why universities might choose to avoid supporting USOs recommending USOs to industrial partners could, if those USOs failed to perform, potentially undermine industrial partners' trust in the academics (Guerrero and Urbano 2012). We therefore contend that it is important to answer this question of why would universities choose to support their USOs to gain a more systematic understanding of university support for high technology entrepreneurship.

Universities are highly complex, loosely coupled organisations undertaking many kinds of activities and with a range of different missions, and therefore to understand universities' decision-making 
choices in terms of balancing competing interests and demands it is possible to use a stakeholder model (Amaral and Magalhaes 2002). Freeman (1984) defined an organisation's stakeholders as those with a stake in the outcome of an organisation's activity. This interest in outcome became important with the rising importance of new public management pioneered in many countries' higher education systems (Kickert 1995; Landsbergen et al. 1992). In this context, universities were formalised into managerial organisations, shifting autonomy towards managers to manage their resources to best achieve goals set by public actors (Fried 2006). For universities, this shift in managerial culture moved away from collective decision-making towards hierarchies in universities (Deem et al. 2007). Universities' stakeholders maybe internal as well as external, and Jongbloed et al. (2007) produce a comprehensive taxonomy of these stakeholder sets.

A stakeholder's importance to an actor is defined as 'salience', possession of attributes important to that actor (Mitchell et al. 1997). Mitchell et al. define salience as the consequence of three variables, power (coercive, utilitarian, and normative), legitimacy (individual, organisational, societal) and urgency (time sensitivity, mission criticality). With universities facing pressures from a variety of sources, as well as potential resistance internally, supporting USOs could be far from universities' wider interests given that they are very demanding: with very few USOs ever covering the costs that universities incur in supporting them, they cannot expect to be seen as being important (Auerswald and Branscomb 2003; Dill 1995; Enders and Boer 2009). We conceptualise Bruneel et al. (2010)'s barriers between USOs and universities as manifestations of USOs' lack of salience to universities as stakeholders. When universities are faced with a decision over how to deal with USOs, the interests of the USO are easily overruled when they come into conflict with other interests.

Bjørkquist argues that networks of relationships between stakeholders can institutionalise what she calls 'stakeholder regimes' (Bjørkquist 2009). Pressure from more salient stakeholders in these regimes - such as government regulators and research funders can encourage universities to shift to become more supportive of USOs (Harrison and Leitch 2010). A variety of classes of stakeholder for the university (both internal and external) can be distinguished who influence the extent to which USOs are seen as important to the universities, or under the class "nice to have but not essential".

The university as an institution has many internal stakeholders with often different interests and aims, and held together through a mix of formal and informal arrangements (Powell and Dayson 2013). University leaders are able to take a strategic view on support for USOs, particularly when they can see that USOs bring resources into the university that strengthen core activities. USOs might also have strong voices in formal governance bodies, whether as members of governing bodies, or as entrepreneurship or technology transfer committees. University support units that are specifically responsible for supporting USOs are a main internal stakeholder for universities, although these are often peripheral within the university overall structure. Faculties and research institutes typically witness the more problematic side of USOs, taking people away from research, taking up space and researcher time, although benefits may come through contributing to teaching (e.g. through placements or guest lectures) and research (as users, co-researchers, funders). There are also structures that govern university business in areas seemingly unconcerned with USOs, but whose decisions affect the university interest in supporting USOs - if promotions committees see entrepreneurial activity as appropriate for tenure or promotion, then academics are less discouraged in supporting entrepreneurial activity.

External stakeholders are those outside the university who have a strong interest in the outcomes the universities produce, and who have resources that universities require that encourage 
universities to consider their views (Benneworth et al. 2011). There are firms who are already engaged with the university around technology transfer, shareholders in USOs or partner companies, licensing university technologies or investors in those companies. Innovation support agencies are also stakeholders, as USOs represent potential clients for them, whilst regional and national policy-makers can use USOs to demonstrate their innovation policies success. Research funders have in recent years become increasingly interested in demonstrating the societal addedvalue of research funding through entrepreneurship and USOs (Vincett 2010), whilst education ministries and university regulators may make supporting instruments (Rasmussen and Rice 2012), and facilitate or hinder universities' intellectual property strategies. Financiers and property developers can regard science parks and real estate developments as potentially profitable, whilst companies and services that provide USOs with services can benefit with increasing customer numbers.

USOs are extremely unlikely to be very strong stakeholders for universities (with the exception of the rare cases where they become highly profitable) (Benneworth, 2007). Individual support activities (e.g. entrepreneurship education programmes or start-up venture financing) may have an occasional outside supportive stakeholder (a funder). They are unable individually to be able to mobilise strong networks of stakeholders who can make the university more reactive to and supportive of USOs in their overall stakeholder regime. It is therefore necessary to consider how USO support activities may attract broad coalitions of support in the overall stakeholder regimes, considering not just single support activities but broader technology transfer 'service bundles' (Benneworth et al. 2004; Crow and Bozeman 1987; Miles 2005). These bundles create activities which make resources available to USOs and support their competencies, are supported by powerful (salient) external university stakeholders, and are positively supported (or at least not too actively resisted) by internal stakeholders. Service bundles bring together diverse groups of stakeholders in supporting USOs and hence embodying the value of supporting USOs to the university, hence answering the "why?" question for university support for their USOs.

With service bundles we are here thinking of constellations of activities that are broader than individual projects, but provide coherent ecosystems within which individual projects, instruments or policy interventions add value to the USO competency. An example of this is where a science park becomes more than a physical real estate development project but also starts to function as a knowledge community precinct and thereby provides active incubation to hosted firms, facilitating USOs accessing entrepreneurial competencies (Benneworth and Ratinho 2014). This links firms and the university in different ways (physical, organisational, virtual, financial) and the university directly benefits in terms of its teaching, research and financial interests. This in turn creates a set of automatisms where USOs seeking help are given the benefit of the doubt - in effect the why question is pre-answered for them ("why wouldn't we help start-ups?").

We therefore argue that university capability to support USOs relates to "the capability to provide supportive ecosystems which support the development of USOs' entrepreneurial competencies in a way that also meets the needs of universities' internal and external stakeholders."

Service bundles are assembled in response to stakeholder pressures and therefore meet a wider set of stakeholder needs than just those of USOs. Service bundles must fit with internal stakeholders' needs, both fitting with the universities' own governance style as well as supporting core activities around teaching \& research. Over the past years various approaches have been developed to illuminate universities' roles in regional development reflecting different underlying models (Goldstein, 2010; Uyarra, 2010). We here distinguish two models where universities have activities targeting regional economic development, namely the entrepreneurial university $(\mathrm{EU})$ and the 
regional innovation system university (RISU) model. The EU model claims universities promote regional development comes through their patenting, licensing and academic spin-off activities. The RISU takes a broader perspective, by including "softer" forms of knowledge transfer relating not only to direct innovation activity, but also to improving the policy, intermediary and cultural innovation environment (Gunasekara, 2006; Lundvall, 2007; Tripplet al., 2014).

To address our overall research question, we conceptualise university contributions to regional economic development as coming via "knowledge spillovers" (Benneworth\& Charles, 2005; Drucker \& Goldstein, 2007). Knowledge spillovers have localised dimensions, creating knowledge resources more easily accessed by physically proximate actors (Ponds et al., 2010). Given that innovation is resource-constrained, ready availability locally of certain knowledge resources can enable innovation activities drawing on those resources, thereby stimulating knowledge based regional development. To date research on university structure and regional engagement has split between small-scale case studies of organisational forms (Healy et al., 2014) alongside quantitative analyses of which kinds of universities produce regional outputs (Drucker \& Goldstein, 2007). Few analyses have directly asked how does universities' underlying internal organisation creates localised spillover effects.

Implemented concept demonstrated that it is possible to break the barriers to entrepreneurship that the general environment raises. Additionally, the project team managed to create in a pilot form a structured framework that raises awareness, activates the necessary institutions and create the appropriate networks. However, this pilot project does not replace a consistent effort by the regional stakeholders to build al the required conditions that the supportive structures and operational environment require for developing a sustainable spin-off generator for the region. Our experience is that without all the supportive elements in place the positive results will be scattered and faded immediately after the project finishes. Such incentives should be used by the regional stakeholders to 'buy time' in order to organise the structural elements of the framework and to use the initial results as examples convincing sceptical actors.

Another bright example of an entrepreneurial university is the National University of Singapore (NUS). In particular, the NUS has implemented numerous policy reforms, leading generally towards creating conditions that are "inventor friendly" and developing a culture of entrepreneurship both inside and outside the classroom; including the introduction of new programmes and revision of existing ones based on academic objectives in entrepreneurship, and adaptation of entrepreneurial principles in how the university is organised and administered.

\section{CONCLUSION}

Spinoffs are one of the rare yet significant engines of direct commercialization of university intellectual property. They are a valuable entity because of the various benefits they bring to universities and society at large; they are a source of local and national economic growth with the capability of providing significantly higher revenue to the universities than licensing (Bray and Lee 2000) as a result of equity partnerships between universities and spinoffs.

In this article, we first presented what university spinoff are by examining and synthesizing existing definitions. Second, we discussed why university spinoffs are needed in light of past scholarly work stating their economic and social benefits. Finally, we examined how university spinoffs are created by reviewing three existing models of university spinoff creation and then proposing a more comprehensive multistage model based on the gaps we identified in the existing models. 
The focus of this study was to develop a wider understanding of university spinoffs for those who are interested in knowing about and researching academic entrepreneurship. The multistage model of university spinoffs proposed in this study can be used by scholars in the area of academic entrepreneurship to build case studies and do phenomenological studies. These studies can be undertaken in universities that promote spinoffs to identify variations in the capabilities, funding, and licensing of spinoffs. Statistical generalizations can be possible in future studies that take into account causal relationships between identified competencies, attempts to patent the invention or innovation, spinoffs created, and economic value generated in large-scale survey-based studies. However, care should be taken by researchers doing such studies because bi-causality can be an inherent characteristic of this kind of data, where more than one variable can influence or cause change in another variable.

\section{REFERENCES}

A Guiding Framework for Entrepreneurial Universities (2012). https://www.oecd.org/site/cfecpr/OECD\%20Entrepreneurial\%20Universities\%20Fram ework.pdf

Boh, W.F., De-Haan, U., Strom, R. (2016). University technology transfer through entrepreneurship: faculty and students in spinoffs. (p.p. 661-669). The Journal of Technology Transfer,.41(4).

Branscomb, L. M., Kodama, F., \& Florida, R. L. (Eds.). (1999). Industrializing Knowledge: UniversityIndustry Linkages in Japan and the United States. Cambridge, MA: MIT Press.

Clarysse, B., Tartari, V., Salter, A. (2011). The impact of entrepreneurial capacity, experience and organizational support on academic entrepreneurship. (pp. 1084-1093). Research policy, 40(8).

Cohen, W. M., Florida, R., Randazzese, L., \& Walsh, J. (1998). Industry and the Academy: Uneasy Partners in the Cause of Technological Advance. In R. G. Noll (Ed.), Challenges to Research Universities (p.p.171-199). Washington, DC: The Brookings Institution.

Di Gregorio, D., Shane, S. (2003). Why do some universities generate more start-ups than others? (p.p. 209227). Research Policy, 32(2).

Etzkowitz, H. (2003). Research Groups As 'Quasi-Firms': The Invention of the Entrepreneurial University. Research Policy, 32(1): (p.p. 109-121). http://dx.doi.org/10.1016/S00487333(02)00009-4

Geuna, A., \& Nesta, L. J. 2006. University Patenting and Its Effects on Academic Research: The Emerging European Evidence. Research Policy, 35(6): (p.p. 790-807. http://dx.doi.org/10.1016/i.respol.2006.04.005

Hague, D., Oakley, K. (2000). Spin-Offs and Start-Ups in UK Universities. London: Committee of ViceChancellors and Principals of the Universities of the United Kingdom.

Hindle, K., \&Yencken, J. 2004. Public Research Commercialisation, Entrepreneurship and New Technology Based Firms: An Integrated Model. Technovation, 24(10): (p.p. 793-803. http://dx.doi.org/10.1016/S0166-4972(03)00023-3

Jones, R. F., \& Gold, J. S. (2001). The Present and Future of Appointment, Tenure, and Compensation Policies for Medical School Clinical Faculty. Academic Medicine, 76(10): (p.p. 993-1004). http://www.ncbi.nlm.nih.gov/pubmed/11597838

Lerner, J. (2004). The University and the Start-Up: Lessons from the Past Two Decades. The Journal of Technology Transfer, 30(1-2). p.p. 49-56. The Journal of Technology Transfer. (http://dx.doi.org/10.1007/s10961-004-4357-8 
Lowe, R. A. (2002). Invention, Innovation, and Entrepreneurship: The Commercialization of University Research by Inventor-Founded Firms. Doctoral dissertation. University of California, Berkeley.

Ndonzuau, F. N., Pirnay, F., \&Surlemont, B. 2002. A Stage Model of Academic Spin-Off Creation. Technovation, 22(5), pp. 281-289. http://dx.doi.org/10.1016/S0166-4972(01)00019-0

Pirnay, F., Surlemont, B., Nlemvo, F. (2003). Toward a Typology of University Spin-Offs. Small Business Economics, 21(4), pp. 355-369. http://dx.doi.org/10.1023/A:1026167105153

Powell, W. W., \& Owen-Smith, J. (1998). Universities and the Market for Intellectual Property in the Life Sciences. Journal of Policy Analysis and Management, 17(2), pp. 253-277. http://dx.doi.org/10.1002/(SICI)1520-6688(199821)17:23.0.CO;2-G

Rasmussen, E., Borch, O.J. (2010). University capabilities in facilitating entrepreneurship: A longitudinal study of spin-off ventures at mid-range universities. Research Policy. 39(5), pp.602-612.

Shane, S. A. (2004). Academic Entrepreneurship: University Spinoff.

Vohora, A., Wright, M., Lockett, A. (2004). Critical Junctures in the Development of University High-Tech Spinout Companies. Research Policy. 33(1), pp.147-175. http://dx.doi.org/10.1016/S0048$\underline{7333(03) 00107-0}$

Walter, S.G., Parboteeah, K.P., \& Walter, A. (2013). University Departments and Self-Employment Intentions of Business Students: A Cross-Level Analysis. Entrepreneurship Theory and Practice, 37(2), pp.175-200.

Wilson, K. (2008) Entrepreneurship Education in Europe in J. Potter, Entrepreneurship and Higher Education, Entrepreneurship and Higher Education, OECD, Paris.

\section{ABOUT THE AUTHORS}

Svetlana Viktorovna Shvedova: dstu_oms@mail.ru

Irina Mikhailovna Maevskaya: oms.internal@yandex.ru 